\title{
Faith, Flight and Foreign Policy: Effects of war and migration on Western Australian Bosnian Muslims
}

\author{
Daniel Vujcich
}

\begin{abstract}
This article examines the nexus between war, religion and migration through a series of qualitative interviews with Bosnian Muslim humanitarian entrants to Western Australia. By utilising a three-tiered model for assessing religiosity, the interviews reveal that a substantial number of participants placed a greater emphasis on Islam during the Balkan conflict. The way in which individual religiosity was expressed upon resettlement in Western Australia was largely determined by pre-migration religiosity and postmigration contact with other Muslims. In particular, migrants with a low level of Islamic knowledge tended to internalise the values and ideas of more conservative Muslims upon arriving in the receiver-nation. Meanwhile, those with a well-developed pre-migration understanding of Islam tend to resist outside influence and continue their original beliefs and practices. The findings demonstrate that conflicts at the state level frequently precipitate psychological crises of identity at the personal level; this in turn has an effect on the cultural and political landscape of migrant receiving nations.
\end{abstract}

Keywords: religion, migration, conflict 


\section{Introduction}

The 'War on Terror' was launched in an effort to restrain and deter some of the more violent consequences of religious fundamentalism. Yet, for many, the war is regarded as having had the opposite effect. A report produced by the National Intelligence Council has 'found that the U.S. invasion and occupation of Iraq has helped spawn a new generation of Islamic radicalism' (Mazzetti 2006). Needless to say, the risks of radicalism are not confined to the actual war zone. In a world of fluid borders and mass migration, ideology is a readily exportable commodity.

While numerous academics have explored the relationship between 'war and religion' and 'migration and religion', few have examined the way in which all three variables interact with one another. Given that we live in a world in which individuals are often forced to migrate as a result of war and religious persecution, such a deficit in scholarly analysis ought to be addressed. Clearly, policy makers need to be aware of the way in which conflicts have the potential to affect nations far removed from formal hostilities.

This Article uses a series of interviews conducted with Bosnian Muslim refugees living in Western Australia to explore the impact of war and forced migration on religious identities. There are, broadly speaking, three reasons why Bosnian Muslims living in Western Australia are an appropriate sample group within which to examine these trends. First, the predominately secular nature of Bosnian society before the Yugoslav civil war makes it easier to discern whether the conflict had an effect on religiosity. Secondly, the fact that there were only 1,622 Bosnian Muslims living in Australia prior to the war (ABS 2001: E05) means that it is possible to determine the way in which postwar entrants shaped the practices and institutions of this migrant community. Finally, the low numbers of pre-war Bosnian Muslim migrants also enables us to examine the extent to which the community was affected by, or sought support from, other ethnic Muslim groups.

The research reveals that a significant proportion of the sample placed a greater emphasis on Islam during the war. In most cases, religion remained important after migration and, in fact, different ways of negotiating the faith were often discovered in the new context. In particular, the types of ethnic and religious institutions available in the receiver-society played an important role in shaping the religious attitudes and practices of the interviewees.

\section{Identity, conflict and migration}

In recent years, and contrary to classical realist theories, identity has come to assume an important place in the study of international politics. The proliferation of ethnic conflicts, the resurgence of secessionist sentiments, the rise in terrorism and the creation of supranational organisations have challenged the assumption that politics is a game that only diplomats and statesmen play. The most recent, and perhaps important, analytic shift in this regard has been the recognition of the key role that religion plays in shaping both domestic and global events. Religion provides followers with a vision of justice, a vocabulary for support and dissent and a vehicle for forging transnational relations (Williams 1996: 368). 
That said, a proper inclusion of religious identity in the equation of political dynamics must recognise that religious identities are neither static nor totalising (Melucci 1997: 84; Pratt 1998: 26). We formulate our sense of self both in relation and in opposition to our surroundings; this includes political context and the identities of those around us. It is therefore logical to suggest that a change in environment might precipitate a reassessment of identity (Seul 1999: 555).

Political scholars of Islam commonly observe that religious revivalist movements have a tendency to rise out of the ashes of a dire military defeat. The Arab nations' shocking loss in the Six Day War is often described as a catalyst for Islamic resurgence in the 1970s (Esposito 1991: 41; Esposito 2002: 8). Similarly, the introduction of Shari'ainspired legislation in Pakistan could be said to have its roots in the bloody secession of Bangladesh that resulted from the Indo-Pakistan War (Yasmeen 2003: 75). More recently, reports have indicated that a rising tide of Islamist rhetoric is surfacing in Iraq following the invasion of coalition forces in 2003. In the words of one Iraqi man, 'God uses many tools ... America's brutality has caused many to understand that Islam is the answer to our problems' (Murphy 2004: 1).

Such observations find support in a growing body of psychoanalytical studies that explore the ways in which individuals respond to negative life events. For instance, a survey found that ' 42 percent [of Israelis] reported an increase in private prayer and/ or traditional observance' (Arian et al. 1993: 245) when faced with the threat of Iraqi missile attacks in 1991. A heightened emphasis on religious coping mechanisms was also discovered among Christians living in Oklahoma City during the time of the Federal Building bombing (Pargament et al. 1998) and American Judeo-Christian students with family members and close friends serving in the Gulf (Pargament et al. 1994).

Several reasons for the positive link between religious coping and negative life events can be discerned. Some commentators (for example, Selby 2002; Faber 1990; Simon 2002) argue that religious resurgence may reflect a need for order and stability during times of great socio-political upheaval. Many individuals find comfort in the constancy of ritual. By participating in repetitive practices such as the recitation of prayers, individuals are temporarily transported out of a chaotic existence and into a world of fixed certainty. Others scholars (for example, Holm 1996; Silver et al. 1988) suggest that the belief in a higher power can serve as a mechanism for overcoming personal feelings of helplessness. Individuals may appeal to God to provide them with the qualities and strengths necessary to deal with challenging situations. Alternatively, some may choose to adopt a more passive approach and place 'all hopes and goals in the trust of God' (Hedayet-Diba 1997: 225; see also Gozdziak 2002(a), 2002(b)).

The increase in religiosity during times of war may also be indicative of a desire to find lessons and hidden meanings in otherwise unfathomable events. It is suggested that the revivalist movements associated with Egypt, Jordan and Syria's defeat in the Six Day War (Piscatori 1986: 26-27) and Pakistan's defeat in the Indo-Pakistan War (Yasmeen 2003: 75 ) fall into this category. Some Muslims wondered whether these outcomes were a punishment from God and, as such, committed themselves to more observant lifestyles; by reassessing their Islamic credentials they sought to pacify what was perceived to be Allah's wrath. 
While it is clear that many individuals turn to religion during times of crisis, there is evidence to suggest that the opposite can be true. Negative experiences may cause some to feel 'angry with or distant from God' (Pargament 1993: 508). Such indignation and dissatisfaction may derive from a sense of abandonment or betrayal. Victims are left asking why a benevolent and all-powerful God did not or could not intervene to prevent their suffering (Guthrie 1980: 193). The absence of a clear answer often results in a rejection of religion. Individuals may instead draw upon a range of other coping mechanisms; these could include turning to family, friends, and professionals for emotional support, internalising negative feelings, and attempting to focus on the positive aspect of the situation.

Of course, conflicts inevitably lead to displacement and, with this, a new context for the manifestation of religion. It is therefore also necessary to examine the way in which religious identities are (re)formulated in new locations. Waardenburg's 'trajectories of identity' (1988) serve as a useful starting point for mapping the range of transnational manifestations of faith. At one end of Waardenburg's spectrum is the 'secular option'. This involves deemphasising or discarding one's faith-based identity and replacing it with an ethnic, national, cultural, political, gendered or other non-religious label as the primary frame of reference. Often migrants pursue this trajectory as a protective mechanism. For instance, some Iranians living in Los Angeles began to downplay their 'Muslimness' in the aftermath of the Iranian hostage crisis because they feared that an association with Islam during such a precarious time might lead to violent reprisals or other forms of persecution (Saah et al. 2002: 453; Mazrui 1996: 499).

Meanwhile, the 'ethnic-religious' trajectory is generally comprised of migrants who choose to associate with a specific group of coreligionists who speak the same language and share similar cultural characteristics. Within the Australian context, Pakistani, Indian and Bangladeshi Muslims have tended to adopt this approach (Bilimoria 1997: 747; Johns et al. 2002: 201). A similar phenomenon has been observed among some Muslim communities in North America: 'Pakistanis tend to sit together [in mosque], as do Egyptians and so forth' (Sonn 1994: 286; see also Kelley 2002: 142). Such communities are more likely to maintain regionally-specific forms of dress and customs.

At the far end of the spectrum, the 'universal-religious' option involves the abandonment of parochialism in favour of more normative and homogenised expressions of faith. For instance, Ethiopian Muslims traditionally observed a number of syncretistic rituals including pilgrimages to the shrines of Christian saints (Abbink 1998: 120; Bernal 1994: 40). However, upon arrival in Canada's multicultural community, they tended to engender more scripturalist interpretations of Islam (Gibbs et al. 2000: 40). This appears to be a common occurrence in multicultural societies. When faced with a degree of internal pluralism, many communities turn to religious texts in order to discern the 'true essence' of the faith. Indeed, Hindus living in the United States have embarked on a process known as 'Sanskritisation' in an effort to unite an otherwise disparate group of followers (Yang et al. 2001: 279).

While Waardenburg's model is a useful way of understanding how migrants go about constructing a sense of community and identity, subsequent studies point toward the need to acknowledge further trajectories. First, cultural theorists have described the emergence of 'a form of interstitial identity' (Mandaville 2002: 222) that represents 
a fusion of the 'religious' and the 'secular'. Within this mediated space, seemingly incommensurable symbols and practices are juxtaposed in new and previously unimagined ways. For instance, it is not uncommon to see Arab youths in the United States driving Mustangs and Grand Jeep Cherokees with statements such as 'the Qu'ran is the last Revelation' painted onto the bonnets, windows, and side panels (David et al. 2002: 128). While the cars are used to facilitate encounters with members of the opposite sex, the youth feel that the slogans are a legitimate expression of the faith. The two aspects of identity - secular American and Arab Muslim - are seen as complimentary, not contradictory.

Secondly, the effects of globalisation have enabled migrants to manifest transnational expressions of religious identity. For instance, Sikhs living in Australia voiced strong disapproval when the Golden Temple in Amritsar was invaded. It was observed that the event caused 'many men to assert their Sikh identity more strongly and visibly by wearing turbans and growing their hair' (Hinnells 1997: 825; see also Dusenbery 1995: 31). Similarly, Muslim women living in England protested about the treatment of other Muslim women in places such as Bosnia and Kashmir during the 1990s (Werbner 1997: 66).

Emerging from this survey, we can abstract one thematic certainty: migrant identities are, like all identities, multiple and morphous. While South Asian migrants to Britain initially organised themselves along ethnic lines, today religion serves as the principle feature of identification (Knott 1997: 756). Meanwhile, Phillip Lewis (1994: 75) observes that Pakistani Muslims living in Britain emphasised the 'religious' aspect of their identity during the Salman Rushdie controversy and the 'national' aspect in the aftermath of Pakistan's cricket World Cup victory in 1992. Thus, individuals frequently draw upon different frames of reference in accordance with changing contextual needs.

\section{Case study: Bosnian Muslims in Western Australia}

As this discussion indicates, a wealth of literature exists addressing the various ways in which religious identity is affected by both war and migration. These two factors have, however, invariably been assessed independent of one another, thus occluding their often necessary interaction. It is not enough to say that war changes people's perceptions of who they are. The reality of the situation is that people are frequently forced to migrate as a result of war and we must therefore ask what happens to that notion of selfhood when another major event such as migration occurs. Here, the variables of identity, war and migration will be linked by examining the experiences of Bosnian Muslim humanitarian entrants to Western Australia.

Barely a handful of studies exist which seek to explore the role of religion in Bosnian Muslim migrant communities. One, conducted by Ai, Huang and Peterson (2003), takes the form of a psychoanalytical survey of refugees living in Michigan and Washington states. It found that a number of participants had employed spiritual coping mechanisms such as prayer and petition as a way of coming to terms with their war-time experiences. A substantial proportion continued to rely upon these religious practices after settling in the United States. In addition to this, Al-Ali, Black and Koser (2001) have noted the emergence of Bosnian Islamic organisations in the United Kingdom and the 
Netherlands. These organisations serve a variety of faith-based needs including the collection and distribution of zakat (alms).

Inquiries into other displaced Bosnian communities have, however yielded different results. Valerie Colic-Peisker (2003: 7) has argued that Bosnian Muslims living in Perth, Western Australia, are 'largely secular'. This claim is based on the general absence of conservative dress codes for women, the community's seemingly relaxed attitude towards the consumption of alcohol and the perceived lack of mass religious celebrations. A similar emphasis on secular identity was observed among Bosnian Muslim refugees living in Israel during the mid-1990s. According to Fran Markowitz (1996: 129), these migrants did not see any 'incongruity in coming ... to a Jewish state' because they supposedly did not have any sense of their 'Muslim' identity. All of the Muslim male refugees in the Israeli sample 'drink beer and cognac, rarely if ever attend mosque and ignore Ramadan’ (Markowitz 1996: 129).

For the purposes of this study, qualitative interviews were conducted with ten Bosnian Muslim migrants to Western Australia. Only post-1991 humanitarian entrants were included in the sample which used snowballing techniques for the selection of interviewees. The interviews were semi-structured and conducted in English and Bosnian between July and September 2004. Participants were invited to begin by discussing their subjective sense of 'Islamic identity'. In the remainder of the interview, participants were encouraged to describe the various ways in which they manifested their sense of religious identity (if at all) and to account for changes over time.

In constructing the interview questions and analysing the material, a three-tiered model - comprising of the personal, social and global - was utilized to understand the ways in which identities are manifested (see Figure 1). The distinctions between the tiers serve an important analytic function because, while in certain respects they may mirror each other, religious identities might be manifested quite differently at each level. Indeed, some individuals may manifest their religious identity in one tier and not another.

\section{Figure 1}

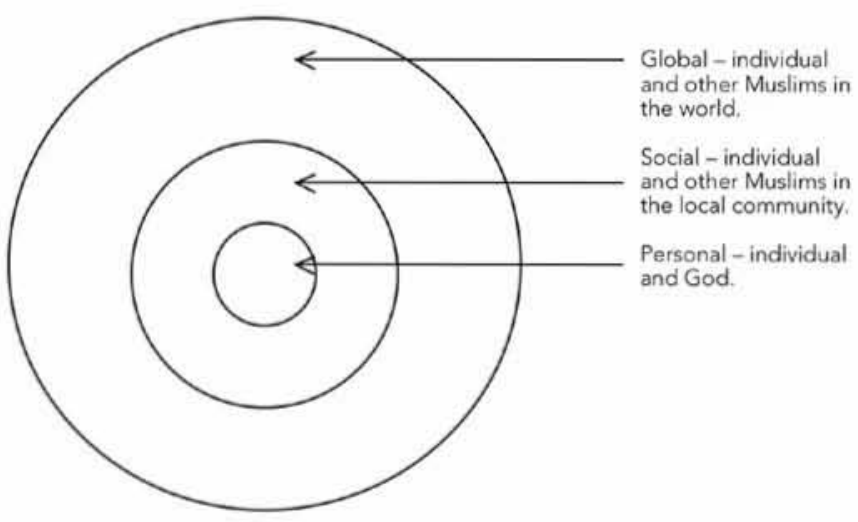

Tier one represents an individual's personal relationship with God. This is generally manifested through observance of the pillars of Islam which require that every Muslim must: (1) declare that there is only one God and that Muhammad is his final prophet; 
(2) pray five daily prayers; (3) fast during the holy month of Ramadan (referred to by Bosnians as Ramazan); (4) donate a percentage of their annual wealth to charity; and (5) perform a pilgrimage to the city of Mecca ( $h a j j)$. Traditionally, followers of the Islamic faith are also expected to abstain from the consumption of alcohol, pig-based products and other non-halal foods and are encouraged to attend mosque whenever possible.

Theorists such as Hedayet-Diba (1997) and Ramadan (2002) have argued that the five pillars of Islam should not be used as a totalising check-list. Instead, it must be realised that Islam is a way of life that also encompasses political, social and other elements (Piscatori 1986: 11). Thus, tier two relates to the individual's relationship with other Muslims in his or her local community, including involvement in any religious organisations. Meanwhile, tier three comprises of an individual's relationship with other Muslims in the global political realm, as manifested in attitudes towards foreign policy issues such as the war in Iraq.

At the time of the 2001 Census, the Western Australian Bosnian Muslim community comprised of 610 men and 536 women. The age distribution of the community is represented in Table 1:

Table 1

\begin{tabular}{lccc}
\hline & Male & Female & Total \\
\hline $15-19$ & 68 & 44 & 112 \\
\hline $20-29$ & 86 & 84 & 170 \\
\hline $30-39$ & 129 & 142 & 271 \\
\hline $40-49$ & 119 & 113 & 232 \\
\hline $50-59$ & 63 & 55 & 118 \\
\hline $60-69$ & 35 & 18 & 53 \\
\hline $70+$ & 14 & 9 & 23 \\
\hline Total & 514 & 465 & 979 \\
\hline
\end{tabular}

Table 1 (ABS 2001: E01)

In terms if their educational qualifications, 51 percent of community members have completed secondary schooling (ABS 2001: E11) and approximately one in every three have embarked on tertiary studies (ABS 2001: E16). At least 47 people have completed bachelor degrees; five have attained post-graduate qualifications and the remaining members of this majority have either certificates or diplomas (ABS 2001: E16). Engineering was the most common field of study among men, while 30 percent of educated women specialised in management and commerce (ABS 2001: E15).

Of the 512 adult Bosnian Muslim migrants in the eligible work force, 80 percent are employed (ABS 2001: E17). The vast majority of working males are tradespeople, manual labourers and transport workers (ABS 2001: E18). Meanwhile, Bosnian Muslim migrant women generally work in clerical, sales, service and labour positions (ABS 2001: E18). Only 44 members of the community work as professionals or associate professionals (ABS 2001: E18). These figures are indicative of the fact that a sizeable proportion of migrants undertook their tertiary training in Bosnia and encountered difficulties in having their qualifications recognised in Australia (King 2002: 6). 
Table 2 lists the characteristics of the ten Western Australian Bosnian Muslims that form this study's sample group. The names of the interviewees have been altered and their occupations have been left deliberately vague for the sake of confidentiality.

Table 2

\begin{tabular}{lllll}
\hline & Sex & Age Group & Education & Occupation \\
\hline Ivo & Male & $20-29$ & University & Professional \\
\hline Alen & Male & $30-39$ & University & Professional \\
\hline Emir & Male & $30-39$ & Two years post secondary & Trades person \\
\hline Jusuf & Male & $40-49$ & Two years post secondary & Pension \\
\hline Hasan & Male & $40-49$ & Secondary & Transport \\
\hline Milan & Male & $40-49$ & Two years post secondary & Hospitality \\
\hline Murat & Male & $40-49$ & Two years post secondary & Pension \\
\hline Emira & Female & $40-49$ & Two years post secondary & Manual labour \\
\hline Sanja & Female & $40-49$ & Two years post secondary & Manual labour \\
\hline Edita & Female & $50-59$ & Two years post secondary & Clerical work \\
\hline
\end{tabular}

\section{Conflict and Bosnian Muslim idenity}

All of the interviewees described the significance of Islam before the war in cultural, as opposed to religious, terms. Being a Muslim in Bosnia had very little to do with Qu'ranic literacy or a punctilious observance of the five pillars. The fact that 'the rooftops of mosques and churches almost touched each other' (Karic 1999: 91) meant that, the boundaries between the faiths in Bosnia had become fluid and overlapping, and the roads to God were tangled and tortuous (Mahmutcehajic 1998: 169). Islam had a 'specific Bosnian dimension which ... implied sharing a history and locality with Bosnians of other non-religious traditions' (Bringa 1995: 173). Thus, in rural Bosnia, it was not uncommon to see Islamic practice suffused with folkish, dervish and Christian influences, such as the use of holy water and large rosary beads (Bringa 1995: 169).

Of course, cities such as Sarajevo contained madressahs that advocated a return to more shari'a-minded interpretations of the faith. However, the influences of the communist state were pervasive in these urban centres (Turkestani 1997: 326). Although religion was never outlawed under Tito's government, public expressions of religiosity were discouraged (Bringa 1995: 204). One commentator described most urban and career-minded Bosnians as 'bacon-sandwich-washed-down-with-plum-brandy-Muslims' (Vulliamy 1998: 88). Rather than being a way of life, Islam was simply a token of family heritage, a symbol of tradition or a means of differentiating oneself from 'Serbs' or 'Croats' (Friedman 1996: 222).

Religion began to assume a more prominent role in Yugoslavia with the gradual decline of communism in the 1980s. However, the rise of religion was hastened by the onset of war. According to a former Director of the International Crisis Group in Bosnia, 'the effect of the war ... was to make more and more people who were Muslims by nationality and tradition, Muslim by faith' (Wheeler in Rubin 2002: 14). There were reports that some urban women began to wear the hijab in public, an unprecedented sight in modern Bosnia (Campbell 1998: 1). While many individuals altered aspects of their faith purely of their own volition, others changed in response to outside influence. Certainly, many 
external groups endeavoured to use the internal problems in Bosnia for opportunistic purposes. Following the arrival of 'mujahideen' from Egypt, Afghanistan and the Middle East, it was not uncommon to see green flags, Arabic clothing and pictures of Saddam Hussein at rallies of the once moderate Yugoslav Muslim Party (Zulfikarpasic 1996: 141). There is also evidence to suggest that al-Qaida attempted to actively recruit war-scarred, shell-shocked volunteers who [had] lost all sense of individual identity and self worth' (Kohlmann 2001: 223), although it would appear that their efforts were largely in vain.

Four of the ten interviewees in the present study described the war as a watershed in their commitment to the faith. Jusuf recalls how, as a child, he had once heard his father mutter the name of Allah while slaughtering a sheep in the lead up to Bajram (or Eid). However, Jusuf did not recognise the practice at the time and saw Bajram as a social event: 'It was just a day when we were all drunk' (Interview). That all changed during the war: 'Without food, without water, without electricity ... of course you will start to think about something more powerful than grenades or bombs' (Interview). For Jusuf, the war served as a divine wake up call both for him, and for the wider society. In his opinion, if it were not for the war, Islam in Bosnia would have disappeared or at least become very weak and superficial: 'like decoration' (Interview).

Similarly, Alen recalled that religion played virtually no role in his early upbringing. However, when the war broke out, Alen found his city under siege and, in the years that passed, he witnessed and endured tremendous suffering. These experiences led Alen to reassess his faith: 'You start thinking more about "What happens if I die?" and stuff like that' (Interview). Moreover, Islam provided meaning to the seemingly irrational atrocities that were occurring: 'People were always trying to make sense of what was going on and religions offered an answer. And also finding some higher purpose. You couldn't just say "Okay" to all this dying ... if nobody was going to be responsible for what they do' (Interview). Thus, whenever the rules of conflict could offer no solace, Alen was sustained by a belief in the immutable laws of Allah. The crimes against humanity permitted in this world would not go unnoticed in the next.

Ivo relays a similar story. Because his father was a member of the Communist Party, Ivo described his family as 'minimalist' Muslims before the war; they celebrated Bajram and 'would not indulge in eating swine or pork' (Interview). Apart from that, Ivo's family was 'non-religious'. Ivo was only a teenager when the war began. As the conflict worsened, he was sent to a neighbouring country as a matter of safety. According to Ivo, 'the tragic things that were happening ... induced this longing for God' (Interview). He began to pray as a means of coping with his lonely life in a new country, separated from the ones he loved. Ivo recalls, "before I went to sleep I always said "Allah, please look after my family ... [so] that I get to see them again"' (Interview).

Edita also invoked this notion of 'God as protector' in recounting her war-time experiences: 'I always thought, "God change this. God let me get out of this. God let my children stay alive"' (Interview). Although Edita had observed religious practices for as long as she could remember, Islam took on new and more salient meanings in response to the conflict. When Edita was asked whether she found herself drawing upon her faith during the war, her response was adamantly affurmative: 'Yes. Yes. Yes. That saved me. Those moments when I was helpless, when I could not do anything else ... that is what saved me. That is what saved me' (Interview). 
The remaining six interviewees did not report any increase in religiosity as a result of the war. Three of these interviewees (Sanja, Hasan and Milan) had never practiced any formal aspect of the Islamic faith, while the remaining three (Emir, Murat and Emira) had. During several of the interviews it was suggested that only secularism or, alternatively, a moderate and uniquely Bosnian approach to Islam, could guarantee the survival of a multi-ethnic society.

For instance, both Sanja and Hasan cited their marriage to non-Muslims as the reason behind their secular outlook. Sanja recalls waking up early one morning to the sound of a man's voice being projected over a megaphone: 'Muslim people prepare yourself [sic]. Today, at eight o'clock, you must leave this town' (Interview). However, she and her Serbian Orthodox husband decided to remain in the town together. 'So many mixed marriages, most of them who are Muslim [went] and the other party stayed,' Sanja said. 'But ... me and my husband didn't let politics split us' (Interview). Sanja disapproved of those who 'changed overnight' (Interview). She described how her Orthodox neighbours began to baptise themselves, how her colleagues suddenly started to treat her differently and how people started to talk about 'how Muslims needed to be killed until the last one' (Interviews). Sanja saw secularism as a pre-condition for peaceful co-existence.

Similarly, Emir recounted the way in which, as a member of the multi-ethnic Bosnian army, he witnessed the emergence of certain 'religious' paramilitary groups. Emir spoke of them in a critical tone: 'They prayed everywhere. I don't like to pray everywhere ... You have a place for praying, like a mosque' (Interview). Like Sanja, he regarded an increase in public religiosity as a sign of disunity: 'In [the] Bosnian Army [there were] Catholic people, Muslim people, Orthodox people. We never follow that - to be more religious' (Interview).

\section{Migration and Bosnian Muslim identity}

Using the three-tiered model, it is now possible to explore how Bosnian Muslims have chosen to manifest their religious identities in a post-conflict, post-migration context. The interviews uncovered a difference in the way that the 'religious' aspect of Bosnian Muslim identity was manifested on both a personal and social level in the early period of post-war resettlement. Emir and Edita - who practiced some of the formal aspects of their faith prior to the conflict - continued to engender a distinctly 'Bosnian' (read, liberal) approach to Islam after the act of migration. Edita explained it thus: '[Observe] Ramazan? You can, but you don't have to. Praying? You can, but you don't have to. When you can, you do it. When you can't, you don't' (Interview). Emir also admits that he does not consider it necessary to strictly follow the five pillars. Indeed, the realities of life in Australia have forced him to prioritise his career over his religious practices. For instance, although Emir no longer fasts during Ramazan on account of the Australian heat, he nevertheless honours the occasion in other ways such as hosting iftar meals for his friends and family. Since both Edita and Emir had practiced their faith prior to the war, their Islamic characters were well formed. Therefore, they did not feel pressured to alter their approach to Islam after arriving in Australia. Their decision to adopt an ethnicreligious trajectory is facilitated by the fact that there is a mesdzidu (prayer room) at the Bosnian Cultural and Recreational Centre ('Centre') that they frequent. 
By contrast, Jusuf avoids the Centre because he objects to its liberal attitude to alcohol consumption - a corollary of the fact that the Centre serves Bosnians of all religious backgrounds. Instead, Jusuf associates with the wider, and predominately scripturalist, Western Australian umma which comprises of people from regions as diverse as SouthEast Asia, the Middle East, Turkey and Africa. The difference may be explained by the fact that, unlike Emir and Edita, Jusuf acquired virtually all of his Islamic knowledge outside of Bosnia. Having spent time as a refugee in a Western European country with a well organised Muslim community, Jusuf developed a relatively conservative approach to the faith. Since arriving in Western Australia, Jusuf has continued to observe the five pillars of Islam closely and has recently taken part in hajj.

Initially, Alen and Ivo demonstrated a similar conservatism. Shortly after arriving in Australia, these two men joined a local Muslim youth organization. However, the organisation was dominated by specific ethnic groups whose understanding of Islam was often quite 'rigid and unaccommodating' (Alen, Interview). In accordance with a traditionalist epistemology, members of the organisation were constantly told, 'You are not a believer unless you pray regularly' (Alen, Interview). Slowly, but surely, both men began to internalise this dominant discourse. According to Alen, it actually came to a point where I was totally obsessed by [prayer]' (Interview).

It was not until Alen gathered the confidence to embark upon his own personal journey of discovery that his sense of Islamic identity began to change: 'I made myself aware of all the literature that existed [and] I started to see prayer in a different light' (Interview). Similarly, Ivo described how, with the passage of time, he became more self-assured and began to ask, 'Should I just blindly follow these people?' Thus, upon arriving in Australia, Alen and Ivo initially felt the need to internalise a homogenised, orthodox understanding of the faith. However, over time, the migration experience also provided the men with access to new information and gave them the freedom to develop their own ideas about Islam. Alen, for instance, relied heavily on the internet where he was exposed to the ideas of progressive scholars. While these ideas have caused him to place less importance on mosque attendance, halal requirements and the five daily prayers, he does not see this as a symptom of secularisation. On the contrary, Ivo has an intimate knowledge of Islamic principles and texts and is able to recite Qu'ranic quotations verbatim. He very much feels like a Muslim.

Another interesting dichotomy is revealed when one considers the 'global tier' of religious identity. At the time that these interviews were being conducted, one of the most important international Islamic issues was the U.S.-led invasion and occupation of Iraq. Members of the Bosnian Muslim sample group were therefore invited to describe their own perceptions of the war. While all of the interviewees in this study disapproved of America's actions, they interpreted the primary reason for the Iraq war in two ways, one secular and the other religious. One the one hand, there are those who drew upon the war-for-oil thesis. According to this argument, the United States' ambition to depose Saddam Hussein and install a democratic, pro-American Iraqi government in his place was motivated by a desire to get contracts for American oil companies previously excluded from Iraq. On the other hand, there were those who saw the 'War on Terror' as a 'War against Islam'. 
Interestingly, those interviewees who manifested their religious identities on a personal or social level invariably invoked the more secular war-for-oil thesis to explain the Iraqi invasion. Indeed, Ivo explicitly rejected the role of Islamophobia: 'I think that it had nothing to do with the country being Muslim. Americans have been invading countries all over the place for the last fifty years' (Interview). On this point, Alen concurs: 'I am not one of these people who have to see everything as "we Muslims are the victims of conspiracy or of forces which want to destroy Islam”. I see it from a more pragmatic point of view' (Interview). The fact that these interviewees did not explicitly draw upon their religious identities to discuss foreign policy is consistent with the fact that each person has intersecting loyalties that influence their ideas and beliefs in different ways. Secular and religious identities are hence not mutually exclusive.

Inversely, two of the three participants who did not manifest their religious identities in tiers one and two, employed religious ideas and sentiments in tier three when discussing the 'War on Terror'. For instance, Sanja made the following comment: 'They think that Muslims are guilty for everything and sometimes I feel like a Muslim because I am frustrated' (Interview). Although Sanja acknowledged the importance of 'money and oil' (Interview) in the decision to invade Iraq, she also observed that 'this part that is rich with petrol is also Islam. Most of these parts are Islam' (Interview). Similarly, when Hasan was asked whether he believed that the 'War on Terror' was a 'War on Islam' his answer was 'one hundred percent' (Interview). According to Hasan: 'They say "Muslims are terrorists". That is exactly what the Croats and Serbs said about us ... (Interview).

Hasan thus draws upon his experience of being persecuted for being Muslim, to empathise with others who he believes are suffering a similar fate. It seems that Sanja's attitudes are formulated in a similar way. Her discussions on the war in Iraq inevitably led her to make reference to other issues concerning Muslims, particularly Palestine: 'I disagree with what is happening in Palestine because my parents [had to] flee from their house to save their lives as Muslims. And I can't just listen to this and just stay cold. I disagree with this politics. Completely disagree' (Interview).

\section{Conclusion}

The foregoing findings demonstrate both the general principle that citizens do not live in a vacuum impervious to their surroundings, and the more specific fact that the religious identities of citizens are not constructed from the material of abstract theologies. Rather, citizens, and in particular new Muslim Australian citizens, have shaped their religious identities through their experience of conflict and migration, and the interactive effect of these variables.

Conflicts at the state level frequently precipitate psychological crises of identity at the personal level; in working through such difficult experiences, individuals may come to place greater emphasis on their religious identities. For those who are forced to flee, these identities continue to develop within the context of the receiver-nation.

The participants' responses reveal that a range of differing 'trajectories of identity' were adopted - from the secular, to the ethno-religious, to the universal-religious. The trajectories are not necessarily mutually exclusive; nor do they represent total and allencompassing realities. For instance, while two of the respondents were did not observe 
Islamic customs and practices, they nevertheless invoked religious concepts to voice their opposition to events such as the war in Iraq and the Israeli-Palestinian conflict. This apparent anomaly should be of particular interest to government decision-makers. It cannot be assumed that seemingly 'secular' Muslims will remain apathetic or neutral when it comes to policies that affect other Muslims.

A further important finding from a policy perspective is that migrants with a low level of Islamic knowledge may be predisposed to adopt the values and ideas of more conservative Muslims upon arriving in the receiver-nation. Meanwhile, those with a welldeveloped pre-migration understanding of Islam tend to resist outside influence and remain committed to their original beliefs and practices. While this seems to contradict research relating to the experiences of Ethiopian migrants in Canada (Gibbs et al. 2000: 40), the anomaly can be explained by the fact that Perth's Bosnian Muslims have access to a number of specifically Bosnian institutions. The Canadian Ethiopians, by contrast, relied upon multicultural institutions administered by a wider Islamic community. In the Australian context, where the relationship between citizenship and the ways in which Muslims practice their faith has become such a contentious issue, this preliminary finding is worthy of further attention.

\section{Acknowledgments}

The author expresses his immense gratitude to the following people for their abundant wisdom, passion, patience and faith: Associate Professor Samina Yasmeen; Dr. Danielle Celermajer; the loving Vujcich family; the University of Western Australia's Department of Political Science and International Relations and the members of Perth's Bosnian Muslim community. Hvala puno prijatelji.

\section{References}

Abbink, J. (1998) 'A Historical-Anthropological Approach to Islam in Ethiopia: Issues of Identity and Politics', Journal of African Cultural Studies, 11(2), 109-124.

Ai, A. \& Peterson, C. et al (2003) 'The Effect of Religious Spiritual Coping on Positive Attitudes of Adult Muslim Refugees from Kosovo and Bosnia', International Journal for the Psychology of Religion, 13(1), 29-47.

Al-Ali, N. \& Black, R. et al (2001) 'Refugees and transnationalism: the experience of Bosnians and Eritreans in Europe', Journal of Ethnic and Migration Studies, 27(4), 615-634.

Arian, A. \& Gordon, C. (1993) 'The Political and Psychological Impact of the Gulf War on the Israeli Public'. In S. Renshon [ed.], The Political Psychology of the Gulf War: Leaders, Publics and the Processes of Conflict, University of Pittsburgh Press, London.

Australian Bureau of Statistics (2001) Census of Population and Housing, Ethnic Communities Package-Religion Profile (Bosnian Muslims in Australia).

Bernal, V. (1994) 'Gender, Culture and Capitalism: Women and the Remaking of Islamic Tradition in a Sudanese Village' Comparative Studies in Society and History, 36(1), 36-67.

Bilimoria, P. (1997) 'The Australian South-Asian Diaspora'. In J. Hinnells [ed], A New Handbook of Living Religions, Blackwell Publishers, Cambridge. 
Bringa, T. (1995) Being Muslim the Bosnian Way, Princeton University Press, Princeton. Campbell, D. (1998) National Deconstruction: Violence, Identity and Justice in Bosnia, University of Minnesota Press, Minneapolis.

Colic-Peisker, V. (2003) 'European Refugees in (White) Australia: Identity, Community and Market Integration'. Paper presented to the National Europe Centre, April.

David, G. \& Ayouby, K. (2002) 'Being Arab and Becoming Americanised: forms of Mediated Assimilation in Metropolitan Detroit'. In Y. Yazbeck Haddad \& J. Smith [eds], Muslim Minorities in the West, AltaMira, Oxford.

Dusenbery, V. (1995) 'A Sikh Diaspora? Contested Identities and Constructed Realities'. In P. van der Veer [ed.], Nation and Migration: The Politics of Space in the South Asian Diaspora, University of Philadelphia Press, Philadelphia.

Esposito, J. (1991) 'Trailblazers of the Islamic Resurgence'. In Y. Yazbeck Haddad \& J. Voll et al [eds], The Contemporary Islamic Revival: A Critical Survey and Bibliography, Greenwood Press, New York.

Faber, H. (1990) 'The Meaning of Ritual in the Liturgy'. In H. Heimbrock \& H. Boudewinjse [eds], Current Studies on Rituals: perspectives for the psychology of religion, Rodopi, Amsterdam.

Friedman, F. (1996) The Bosnian Muslims: Denial of a Nation, Westview Press, London.

Gibbs, C. and Rothenburg, C. (2000) 'Believing women: Harari and Palestinian women at home and in the Canadian diaspora', Journal of Muslim Minority Affairs, 20(2), 243-259.

Gozdziak, E. (2002) 'Editorial Introduction: Religion and Spirituality in Forced Migration', Journal of Refugee Studies, 15(2), 129-135.

Gozdziak, E. (2002) 'Spiritual Emergency Room', Journal of Refugee Studies, 15(2), 136152.

Guthrie, S. (1980) 'A Cognitive Theory of Religion', Current Anthropology, 21(1), 181203.

Hedayet-Diba, Z. (1997) 'The Self-Object Functions of the Koran', International Journal for the Psychology of Religion, 7(4), 211-236.

Hinnells, J. (1997) 'Comparative Reflections on South Asian Religion in International Migration’. In J. Hinnells [ed.], A New Handbook of Living Religions, Blackwell Publishers, Cambridge.

Holm, T. (1996) Strong Hearts, Wounded Souls: Native American Veterans of the Vietnam War, University of Texas Press, Austin.

Johns, A. \& Saeed, A. (2002) 'Muslims in Australia: The Building of a Community'. In Y. Yazbeck Haddad \& J. Smith [eds], Muslim Minorities in the West, AltaMira, Oxford.

Karic, E. (1999) Essays (On Behalf of) Bosnia, El-Kalem, Sarajevo.

Kelley, R. (1994) 'Muslims in Los Angeles”. In Y. Yazbeck Haddad \& J. Smith [eds], Muslim Communities in North America, State University of New York Press, Albany. 
Knott, K. (1997) 'The Australian South Asian Diaspora'. In J. Hinnells [ed.], A New Handbook of Living Religions, Blackwell Publishers, Cambridge.

Kohlmann, E. (2004) Al-Qaida's Jihad in Europe: The Afghan-Bosnian Network, Berg Publishers, Oxford.

Lewis, P. (1994) Islamic Britain: Religion, Politics and Identity among British Muslims, I.B. Tauris, London.

Mahmutcehajic, R. (1998) 'Muslims and the Others of Europe', Journal of Muslim Minority Affairs, 18(1), 169-176.

Mandaville, P. (2002) 'Muslim Youth in Europe'. In S. Hunter [ed.], Islam, Europe's Second Religion, Praeger, Westport.

Markowitz, F. (1996) 'Living in Limbo: Bosnian Muslim Refugees in Israel', Human Organisation, 55(2), 127-132.

Mazetti, M. (2006) 'Iraq war spawns Islamic radicalism, spy agencies say', The New York Times, 24 September.

Mazrui, A. (1996) 'Between the Crescent and the Star-Spangled Banner: American Muslims and U.S. Foreign Policy', International Affairs, 72(3), 493-506.

Melucci, A. (1997) 'Identity and Difference in a Globalised World'. In P. Werbner \& T. Modood [eds], Debating Cultural Hybridity, Atlantic Highlands, London.

Murphy, D. (2004) 'Radical Islam grows among Iraqi's Sunnis', Christian Science Monitor, 28 July, 1.

Pargament, K. \& Ishler, K. et al (1994) 'Methods of Religious Coping with the Gulf War: Cross-sectional and Longitudinal Analyses', Journal for the Scientifuc Study of Religion, 33(4), 347-361.

Pargament, K. and Olsen, H et al (1992) “'God Help Me” (II): The Relationship of Religious Orientations to Religious Coping with Negative Life Events', Journal for the Scientific Study of Religion, 31(4), 504-513.

Pargament, K. \& Smith, B. (1998) 'Patterns of Positive and Negative Religious Coping with Major Life Stressors', Journal for the Scientific Study of Religion, 37(4), 710724.

Piscatori, J. (1986) Islam in a World of Nation States, Cambridge University Press, Cambridge.

Ramadan, T. (2002) 'Europeanisation of Islam or Islamicisation of Europe?' In S. Hunter [ed.], Islam, Europe's Second Religion, Praeger, Westport.

Rubin, A. 'Bosnia’s Islamic Infusion', The Los Angeles Times, 17 November 2002, 14.

Saah, G. \& Bozorgmehr, M. (2002) 'Secular Immigrants: Religiosity and Ethnicity Among Iranian Muslims in Los Angeles'. In Y. Yazbeck Haddad \& J. Smith [eds], Muslim Minorities in the West, Grey Seal, Oxford.

Selby, J. (2003) 'Ground Zero as Sacred Space', Religious Studies and Theology, 21(1), 75-87.

Seul, J. (1999) '“Ours is the Way of God”: Religion, Identity, and Intergroup Conflict', Journal of Peace Research, 36(5), 553-569. 
Silver, S. \& Wilson, J. (1988) 'Native American Healing and Purification Rituals for War Stress'. In J. Wilson and Z. Harel et al [eds], Human Adaptation to Extreme Stress: From the Holocaust to Vietnam, Plenus Press, New York.

Simon, J. (2002) 'Thoughts on September 11, 2001', Journal of Religion and Health, 41(1), 11-15.

Sonn, T. (1994) 'Diversity in Rochester's Islamic Community'. In Y. Yazbeck Haddad \& J. Smith [eds], Muslim Communities in North America, State University of New York Press, Albany.

Turkestani, R. (1997) 'The Muslim predicament in the Balkans: Tito's Legacy', Journal of Muslim Minority Affairs, 17(2), 325-334.

Vulliamy, E. (1998) 'Bosnia: The Crime of Appeasement', International Affairs, 74(1), 73-91.

Waardenburg, J. (1988) 'The Instutionalisation of Islam in the Netherlands'. In T. Gerholm \& Y. Lithman [eds], The New Islamic Presence in Western Europe, Mansell, London.

Werbner, P. (1997) 'Public Spaces, Political Voices: Gender, Feminism and Aspects of British Muslim Participation in the Public Sphere'. In P. Werbner \& T. Modood [eds] Debating Cultural Hybridity, Atlantic Highlands, London.

Williams, E. (1996) 'Religion and Political Resource: Culture or Ideology?', Journal for the Scientific Study of Religion, 35(4), 368-378.

Yang, F. \& Ebaugh, H. (2001) 'Transformations in new immigrant religions and their global implications', American Sociological Review, 66(2), 269-288.

Yasmeen, S. (2003) 'Pakistan and the struggle for “real” Islam'. In S. Akbarzadeh \& A. Saeed [eds], Islam and Political Legitimacy, Routledge Curzon, London.

Zulfikarpasic, A. (1996) The Bosniak, Hurst, London. 